\title{
A Geological History of the Turkana Basin
}

\author{
CRAIG S. FEIBEL
}

The Turkana Basin preserves a long and detailed record of biotic evolution, cultural development, and rift valley geology in its sedimentary strata. Before the formation of the modern basin, Cretaceous fluvial systems, Paleogene lakes, and Oligo-Miocene volcano-sedimentary sequences left fossil-bearing strata in the region. These deposits were in part related to an early system of rift basins that stretched from Sudan to the Indian Ocean. The present-day basin has its origins in Pliocene tectonic developments of the modern rift, with subsidence making room for more than one kilometer of Plio-Pleistocene strata. Much of this sequence belongs to the Omo Group, richly fossiliferous sediments associated with the ancestral Omo River and its tributaries. Modern Lake Turkana has a record stretching back more than 200 thousand years, with earlier lake phases throughout the Plio-Pleistocene. The geologic history of the basin is one of dynamic landscapes responding to environmental influences, including tectonics, volcanic activity and climate.

The Turkana Basin is a hydrographic and sedimentary system encompassing about $131,000 \mathrm{~km}^{2}$ of northern Kenya and southern Ethiopia (Fig. 1). In its present configuration, the basin is hydrologically closed and dominated by alkaline Lake Turkana, with the Omo River as its primary source of water. As recently as the middle Holocene, it had connections to adjacent rift basins and an outlet to the Nile River. The present-day isolation of the Turkana Basin is in part due to the current water balance, but has at its roots the tectonic dynamics that

Craig Feibel is a geologist at Rutgers University, where he teaches sedimentology, geoarcheology, and the environmental context of evolution. His fieldwork in the Turkana Basin is currently focused on linking modern and ancient depositional systems, and understanding the controls on local environmental change E-mail: feibel@rci.rutgers.edu

Key words: stratigraphy; evolution; Africa; rift valley; hominins

(C) 2011 Wiley Periodicals, Inc.

DOI 10.1002/evan.20331

Published online in Wiley Online Library

(wileyonlinelibrary.com). have controlled accumulation and exposure of the sedimentary strata for which the basin is world-famous. This contribution attempts to synthesize the geologic history of the Turkana Basin with an emphasis on the sedimentary strata associated with the basin's rich paleontological and archeological records.

\section{GEOLOGICAL INVESTIGATIONS}

Exploration and description of the geological features of the Turkana Basin have been under way for over a century. The earliest European explorers to visit the region, Teleki and von Höhnel, ${ }^{1}$ returned with valuable observations on the geology and landscapes they traversed. Other expeditions followed (see bibliography in Coppens and coworkers ${ }^{2}$ ), culminating in Fuchs' ${ }^{3}$ first synthesis of the basin's geological history. These early workers recognized many significant aspects of the basin's geology, from the complex record of lake-level fluctuations to major tectonic and volcanic episodes. One confounding generalization from this early work, however, was the amalgamation of many promi- nent quartzo-feldspathic sandstones into the "Turkana Grits," an assemblage later determined to include strata ranging in age from the Cretaceous through the Pleistocene. ${ }^{4}$

Reconnaissance mapping west of Lake Turkana initiated comprehensive documentation of the basin with a series of geological reports. ${ }^{5-7}$ In 1972-1974, the Omo River Project investigated the lower reaches of the Omo Valley, including mapping and description of its geological exposures. ${ }^{8}$ Field work undertaken between 1980 and 1986 around the eastern and southern periphery of the basin ${ }^{9-13}$ provided the most comprehensive mapping and geological descriptions available for that region.

Beginning in the mid-1960s, paleoanthropological investigations in the lower Omo Valley, ${ }^{14}$ at Koobi Fora, ${ }^{15,16}$ West Turkana, ${ }^{17}$ and elsewhere ${ }^{4,18,19}$ catalyzed geological research in the basin. Although this work has focused heavily on providing context for fossil and archeological discoveries, it has generated much of our current understanding of the basin as a whole. In particular, the development of detailed chronostratigraphic frameworks ${ }^{4,20-23}$ has helped to constrain the geological history of the basin. (Note that the time scale of Gradstein, Ogg, and Smith ${ }^{24}$ is used throughout this paper).

Hydrocarbon and geothermal interest fueled exploration in the southern reaches of the basin and expanded our understanding of subsurface structure, stratigraphy, and petrology. ${ }^{25-27}$ Research focused on deposits beneath the modern lake has also added considerably to our understanding of the structural underpinnings of the system and of both Neogene strata and Holocene sedimentation. ${ }^{28,29}$ 


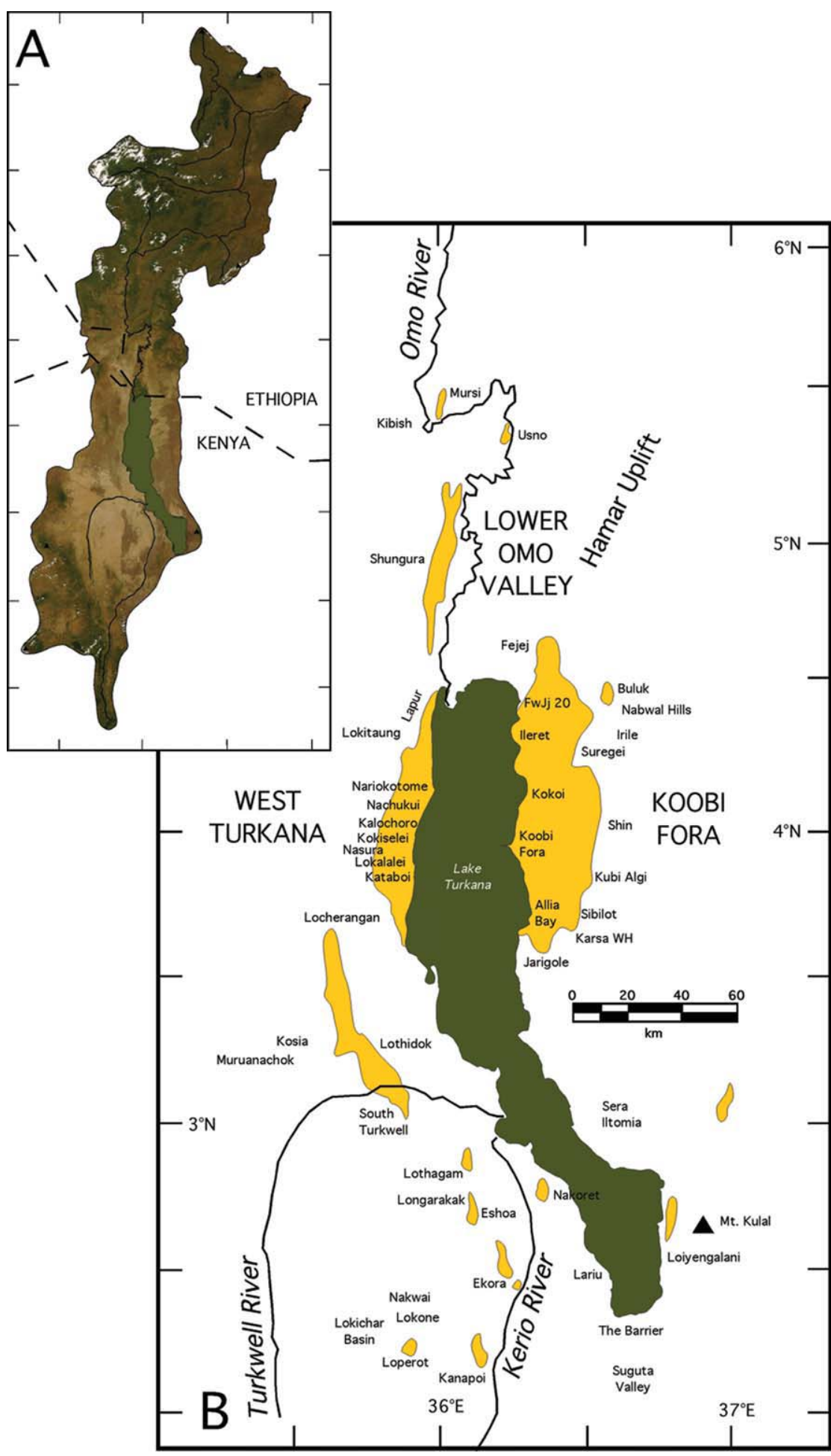

Figure 1. Locality map of the Turkana Basin. A. Extent of drainage network and major geographic features. B. Local geographic terms, fossil localities, and archeological sites.

\section{TECTONIC HERITAGE}

Much of the Turkana Basin lies within the topographic saddle between the Ethiopian and Kenyan
Jurassic-Paleogene Central African Rift System (CARS), ${ }^{30}$ which transected the area as a northwest-southeast basin complex. The CARS basins were responsible for sedimentary accumulations preserved from the Late Cretaceous, ${ }^{31}$ and may have remained an important structural influence into Miocene times. The CARS continued to affect sediment accumulation patterns through the Neogene as preexisting rift structures and topographic lows constrained both basin morphology and fluvial corridors, particularly the Anza Graben leading to the Indian Ocean. $^{32}$

Tectonic activity delineating the modern Turkana Basin began in Early Pliocene times, with subsidence related to the EARS that quickly took on a pattern of alternating half-graben trending northsouth. ${ }^{33}$ Several significant pulses of tectonic activity are recorded in earliest Pleistocene times, when the Hamar Uplift developed, and in a Middle Pleistocene phase of activity that culminated in the modern basinal configuration. During this most recent phase, subsidence along the basin axis has left structural blocks along the margin in topographically higher positions and subject to the erosion that has exposed Plio-Pleistocene sediments, fossils, and sites. Biogeographic $^{34}$ and sedimentary patterns suggest that up to the Middle Pleistocene reorganization, the Turkana Basin preserved elements of the CARS hydrography, including an outlet to the Indian Ocean. Only in the last few hundred thousand years has the basin become a contributory system to the Nile drainage.

Following extensive research, including seismic analyses tied to hydrocarbon exploration, ${ }^{25}$ the detailed structural configuration of the basin is now well understood in many areas. However, recognition of structural bounds and active sub-basins from specific episodes of the past is often complicated. Though sometimes referred to as the Omo-Turkana Basin, there are at least nine structural sub-basins within the tectonic complex associated with EARS development, and a further seven or more older basins related to either the CARS or early EARS. 


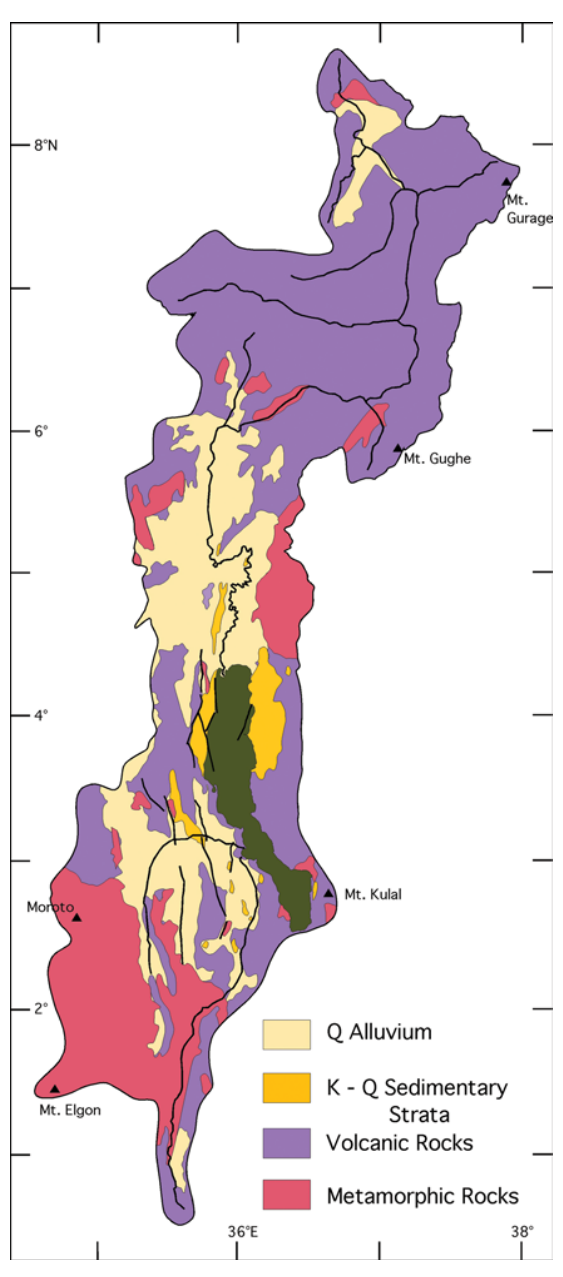

Figure 2. Geological sketch map of the Turkana Basin.

\section{BASEMENT UNDERPINNINGS AND VOLCANIC SUCCESSIONS}

The metamorphic basement in the Turkana Basin (Fig. 2) formed as part of the Mozambique Belt during a Neoproterozoic to Cambrian age mountain-building episode. ${ }^{35}$ These quartzites, gneisses, schists, and amphibolites are the dominant sediment source for much of the clastic sequence deposited during the Neogene. Locally, as in the Omo and at Fejej, the quartzites are important raw material for stone-tool manufacture. ${ }^{36-38}$

Today volcanic rocks (Fig. 2) cover a large proportion of the basin and attain considerable thickness. Late Eocene to Miocene volcanics are dominated by extensive basalts (in excess of $1,000 \mathrm{~m}$ at Lokitaung), ${ }^{6,20}$ along with ignimbrites, trachytes, rhyolites, and other types. ${ }^{39,40}$ At Lothidok, Boschetto ${ }^{41}$ described approximately $785 \mathrm{~m}$ of the Kalakol basalts deposited in latest Oligocene and Early Miocene times. A pulse of nearly basin-wide basaltic effusion produced the Gombe Group, ${ }^{40,42}$ an important Early Pliocene stratigraphic marker. In general, however, after the early Late Miocene, volcanism was considerably less common and more localized within the basin. The volcanic centers associated with Mount Kulal developed after about 2.5 Ma. The Barrier complex separating Turkana from the Suguta Basin was emplaced beginning about $1.4 \mathrm{Ma}$, and the islands within the modern lake are of Late Pleistocene to Holocene age. With the exception of the detailed studies by Watkins ${ }^{40,43-45}$ around the Suregei region and an investigation of the islands within Lake Turkana, ${ }^{46}$ most of the basin's volcanic rocks are known primarily from individual sampling localities and isotopic ages, and through broad reconnaissance mapping. However, these volcanics shaped much of the basin's landscape, are significant contributors to sediment flux and solutes, and are key markers in the chronostratigraphic history of the basin. Volcanic raw materials are also the dominant sources used in manufacture of most of the basin's archeological record. $^{47}$

\section{TURKANA SEDIMENTARY STRATA}

The present-day Turkana Basin encompasses a long and complex sequence of sedimentary strata. The older sediments accumulated within components of the CARS or in isolated depositional basins. Because of small area of outcrops, faulting, or uncertain relationships to broader depositional systems that now lie outside the confines of the Turkana Basin, these sedimentary strata may provide limited windows into earlier stages in the geological history of the region. Often, however, they preserve important paleontological records and are vital keys to understanding evolutionary patterns across Africa. With the tectonic development of the modern basin, an integrated depositional system was established over a much broader area, though the continuity of these deposits has subsequently been disrupted by younger tectonic events and the formation of the modern lake.

\section{Cretaceous Windows}

The oldest sedimentary strata currently recognized within the Turkana Basin are the Cretaceous sandstones and conglomerates of the Lapur Formation and its correlates. The best exposures are on the slopes of Lapur itself, and presumed correlates are known from Muruanachok, Lariu, and Sera Iltomia. ${ }^{26}$ Originally included within the poorly constrained "Turkana Grits," these sediments attain thicknesses of about $500 \mathrm{~m}$ near Lokitaung Gorge, and are preserved as thinner packages on the metamorphic basement in other parts of the basin. ${ }^{31}$ Lapur Formation sediments are exclusively quartzo-feldspathic material derived from the metamorphic basement, representing alluvial fans, braided rivers, and associated paleosols. ${ }^{48}$ They may span up to 50 million years, from the early Late Cretaceous to Late Eocene, though the strata probably sample only a small fraction of that. Fossils of dinosaurs ${ }^{49}$ and other Mesozoic reptiles ${ }^{50}$ have been recovered from the lower part of this sequence. Sedimentary strata, with clasts derived from associated basalts, are also intercalated within the capping Late Eocene basalt flows near Lokitaung, ${ }^{31}$ but thus far have yielded no fossil remains.

\section{Glimpses of the Paleogene}

The volcanism that began in the Turkana Basin in the Late Eocene ${ }^{51}$ became much more widespread in the Oligocene, with thick sequences of basalts and rhyolites extruded, particularly in the western part of the basin. Sedimentary strata of Oligocene age are currently known from three localities in the southwest Turkana Basin. The best-known sequence is in the Eragaleit beds of Lothidok. ${ }^{4,52}$ These beds, which were described in detail by Boschetto, ${ }^{41}$ 
represent the thickest of a series of lenticular sediment bodies intercalated within the Kalakol basalts. These volcaniclastic sediments and associated tephra are typical of localized fluvial accumulations associated with a constructional volcanic terrane. Recently, Oligocene sequences have been reported at Nakwai ${ }^{53}$ near Loperot, and nearby at Lokone. ${ }^{54}$ These fossiliferous localities are both situated on the hinge margin of the Lokichar Basin, where fluvial deposits accumulated alongside a major lacustrine system. ${ }^{26}$ Seismic and coring investigations of the Lokichar Basin $^{55}$ indicate about $7 \mathrm{~km}$ of sedimentary fill. This includes two prominent lacustrine phases represented by shales of Eocene-Oligocene and Oligocene-Miocene age, ${ }^{56,57}$ but these are not known from outcrop. The Oligocene record of the Turkana Basin thus begins to reflect two important themes, accumulation of fossiliferous strata on the margins of major tectonic depressions such as the Lokichar Basin, and accumulations within more localized systems associated with constructional volcanic landscapes as seen in the Eragaliet beds.

\section{Miocene Sedimentary Packages}

The Miocene is well represented in sedimentary strata throughout the Turkana Basin. Early Miocene localities include Irile, Nabwal Hills, Buluk, and Fejej in the Suregei region northeast of the modern lake, and Loperot, Lothidok, and Locherangan to the southwest. The volcanic succession exposed in the Suregei uplands includes several thin sedimentary intervals with associated fossils. All consist of fluvial strata accumulated on a volcanic landscape, with the thickest accumulation in paleo-valleys. ${ }^{45,58}$ The locality of Loperot encompasses several hundred meters of strata ascribed to the Lokhone and Auwerwer formations. ${ }^{55}$ These strata reflect the lateral equivalents of the thick basin-fill of the Lokichar Basin. A fossil ziphiid whale reported from this locality by Mead ${ }^{59}$ suggests the existence of a fluvial corridor to the Indian Ocean at this time.
By far the best sampling of the Early Miocene comes from Lothidok, part of a significant tectonic basin where various localities, including Moruarot, Kalodirr, and Naserte, have produced important hominoid fossils. $^{60,61}$ Boschetto's work ${ }^{4,41}$ demonstrated that the lower interval at Lothidok reflects a complex depositional system, with significant tephra deposits, reworked volcaniclastic sands and gravels, and lahars (volcaniclastic mudflows). This appears to represent a major sedimentary basin, accumulating several hundred meters of strata, but its geographic extent is unclear. Locherangan, ${ }^{62}$ a smaller locality to the north of Lothidok, preserves evidence of a lake at this time, as well as a rich faunal assemblage in associated fluvial deposits.

\section{In the Early Pliocene, the Turkana Basin began to develop into a large integrated depositional system. Subsidence initiated accumulation along the existing drainage networks of an erosional landscape and quickly broadened to the complex of sub-basins that would dominate the region for the next four million years.}

The upper interval of the Lothidok Formation also reflects a complex volcanic landscape, with lava flows, lahars, and abundant tephra, but a significant fluvial system is also demonstrated by the conglomerates, mudstones and sandstone beds with Etheria reefs. As an indicator of perennial flow in fluvial channels, the Nile oyster suggests the presence of a more extensive fluvial network in the region. These strata are also characterized by an increasing abundance of clasts derived from the metamorphic basement.
The sole Late Miocene locality in the Turkana Basin is Lothagam. ${ }^{63}$ Footwall uplift along a major fault there has exposed a window of Late Miocene sedimentary strata beneath a Plio-Pleistocene succession. Like most of the Miocene records from the basin, our understanding is limited by the isolation of the outcrops, but the character of the Nawata Formation fluvial strata reveals that they were once part of a major riverine system. ${ }^{18,64}$ Early deposits show a dominance of local volcanic clasts, but subsequent fluvial strata are dominated by quartzo-feldspathic sediments. Lothagam is particularly interesting in that the fluvial systems are extremely rich in reefs of the Nile oyster Etheria elliptica, again an indicator of perennial flow. Paleosols at Lothagam reflect broad floodplain development, ${ }^{65}$ but the deposits of the Nawata Formation at Lothagam lack any indication of significant lake formation. Only small, shallow floodplain ponds are recorded. ${ }^{18}$

The Miocene sequence of the Turkana Basin demonstrates a dominance of local tectonic effects providing room for sediment accumulation, along with strong influence from local volcanism in lava flows, tephra, lahars, and volcanic sediment supply. There are, however, intriguing hints of a large river system (or systems) associated with metamorphic-sourced sediments, perennial flow, and broader floodplain development. There appears to be a gap in the geologic record from latest Miocene to earliest Pliocene times, after which this relatively localized focus changed dramatically.

\section{The Plio-Pleistocene Sedimentary Basin}

In the Early Pliocene, the Turkana Basin began to develop into a large integrated depositional system. Subsidence initiated accumulation along the existing drainage networks of an erosional landscape and quickly broadened to the complex of sub-basins that would dominate the region for the next four million years. The history of the basin through the Plio-Pleistocene can be traced as a succession of floodplain systems, during which fluvial deposi- 


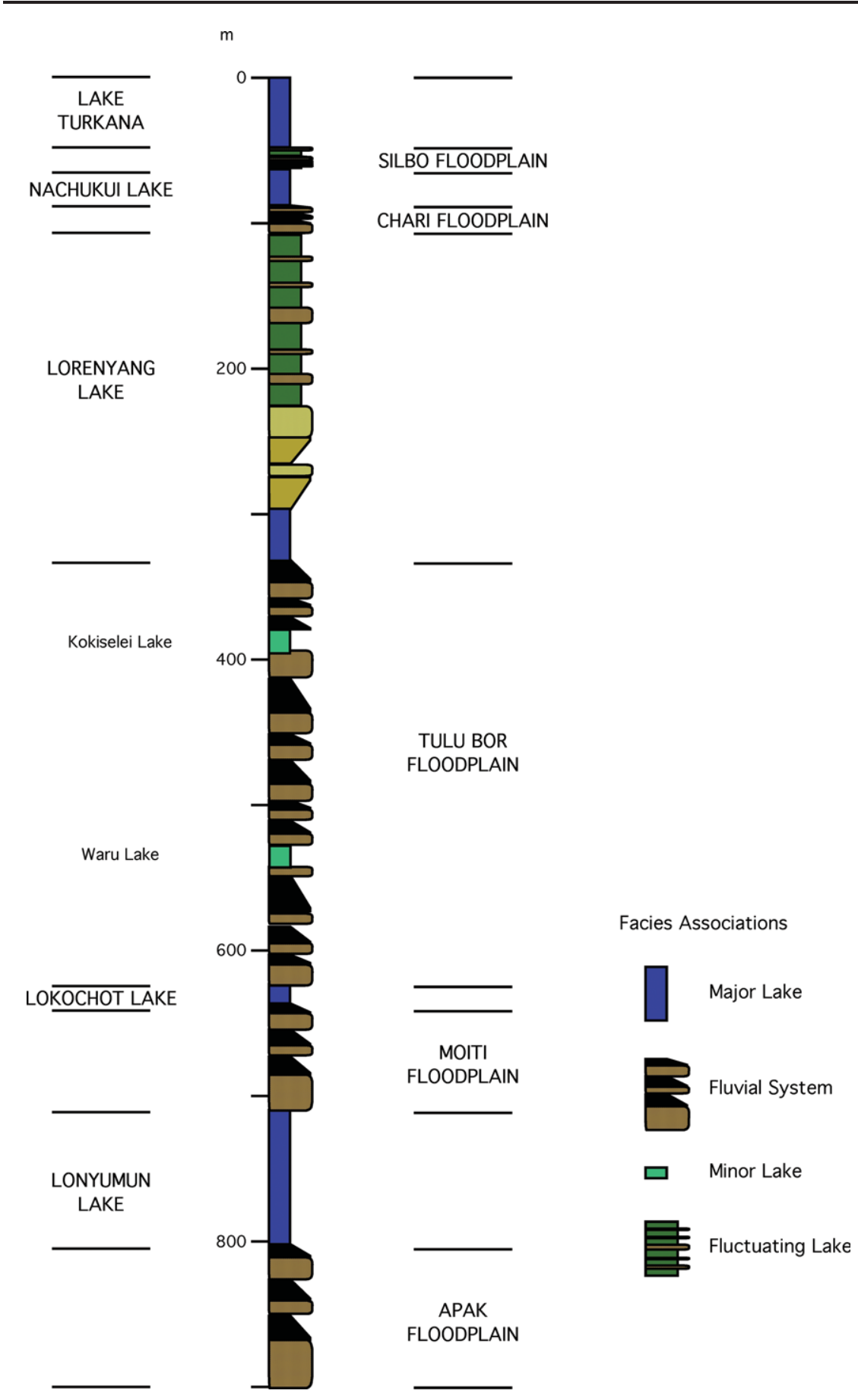

Figure 3. Stratigraphic evolution of the Plio-Pleistocene Omo Group deposits. Composite stratigraphic sequence is shown by major facies associations and subdivided into major landscape systems through time.

tion dominated, and lacustrine phases during which much of the basin was inundated. The primary controls on this pattern were the interplay between accommodation space, the product of subsidence, and sedimentation, working to fill, or overwhelm, the sub- siding basin. The sedimentary strata that resulted from this Plio-Pleistocene episode are collectively referred to as the Omo Group. ${ }^{14}$ The broad geographic extent of this system and the dynamic nature of its major landscape components (rivers, deltas, lakes, volca- noes), make this a complex system to characterize at any particular time. However, the geologic history of this interval can be simplified into a series of major landscape systems (Fig. 3), These systems are closely related to the depositional and postdepositional markers inherited by the sedimentary strata, as well as to the mosaic of habitats and associated communities developed on them.

The earliest deposits of the Omo Group are best developed at Lothagam, where, before 4.24 Ma, the Apak Member documents a transition from an erosional or pedogenic landscape to alluvial accumulation. Comparable records are seen at Kanapoi, and the system may be reflected in sequences at Mursi, Loiyengalani, Karsa, and Ileret. Here, this phase of basin history is called the Apak Floodplain. It is likely that in its earliest manifestation, this fluvial system integrated the ancestral Omo, Turkwell, and Kerio rivers in a through-flowing system that exited the present-day basin confines to the southeast via the Turkana River. ${ }^{32}$ At present, however, highquality records of this interval are restricted to the southern part of the basin. Kanapoi provides a unique window into this complex landscape, where eroded volcanic hills were buried beneath an aggrading alluvial system. ${ }^{19}$ This landscape would have had a mix of residual soils developed on the local volcanic "basement," as well as a variety of floodplain and associated channel habitats. ${ }^{66}$ Both Lothagam and Kanapoi record numerous small-scale tephra deposits through this interval. Preservation of the rich hominin assemblage at the Australopithecus anamensis type site at Kanapoi may have resulted from the rapid burial this tephra influx allowed.

A major reorganization of the Turkana Basin landscape occurred about 4.1 Ma, when the first of the PlioPleistocene lakes, called Lonyumun Lake, developed. ${ }^{67}$ This was the largest lake to ever fill the basin, stretching from Kanapoi to Mursi and from Kosia to Kubi Algi. This lake system accumulated up to $120 \mathrm{~m}$ of sediment in some areas, predominantly claystones and diatomites. Shoreline deposits are uncommon, largely as a consequence of recent erosion 


\section{Box 1. Structural Geology 101}

Understanding the geological evolution of the Turkana Basin requires a working knowledge of how rocks are deformed under stress in a rift setting. In this dominantly tensional environment, the most basic type of large-scale rock fracture is a normal fault. The blocks on either side of the fracture move away from each other as slippage on the diagonal fault plane allows the upper block, called the hanging wall, to move down relative to the block beneath the fault plane, or footwall block. (In case you are wondering, these terms for these rocks are inherited from the mining
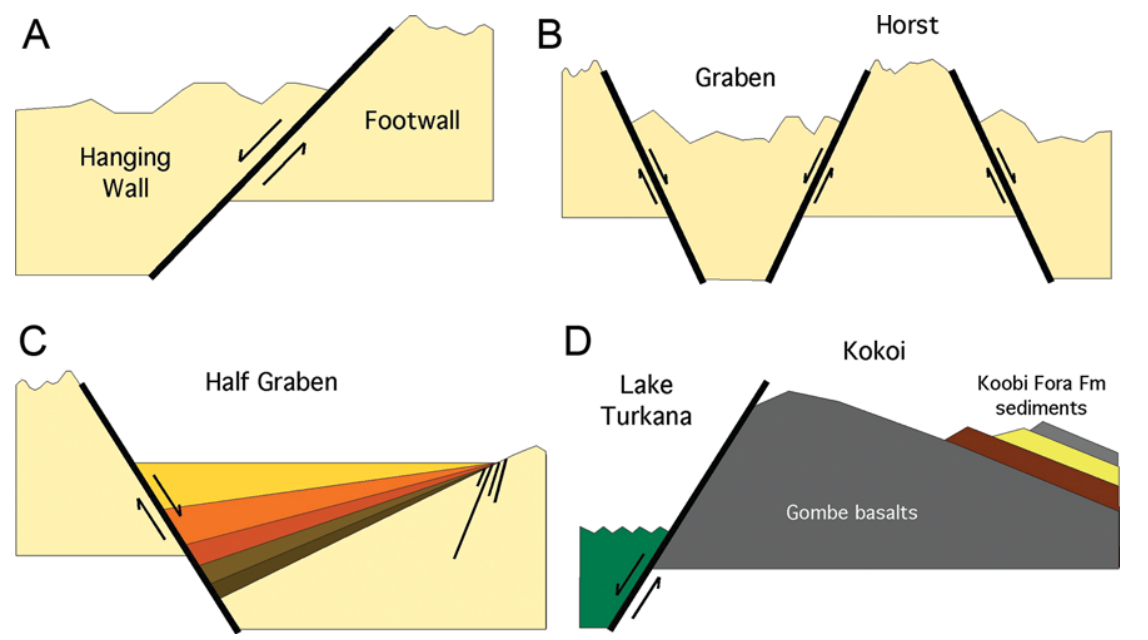

Figure B1. Structural components seen in the Turkana Basin.

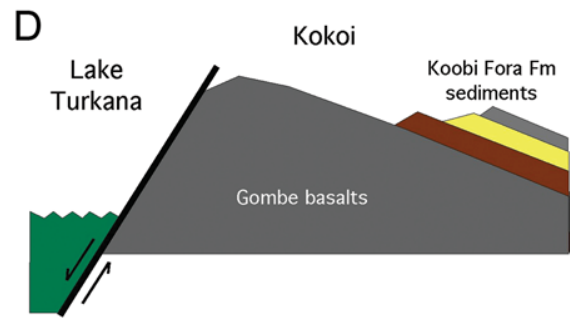

industry, where workers tackled inclined veins of ore. A miner would stand on the footwall of the seam, and could attach his lamp to the hanging wall) (Fig. B1, Part A). Two normal faults inclined toward each other allow a central block to drop, forming a graben. This is the fundamental unit of the classic rift valley. Two normal faults oriented away from one another result in an uplifted central block, termed a horst (Fig. B1, Part B).

In most cases, portions of the rift are composed of multiple fault blocks, arranged in complex fashion. Many rifts are dominated by

the

blocks in which only one major normal fault is involved, with a weakly faulted hinge on the other side of the block, thus forming a half-graben (or a half-horst) (Fig. B1, Part C). Half-graben geometry is typical of most of the subsiding blocks in the Turkana Basin. A fundamental characteristic of sediment accumulation in a half graben is a thickening of individual sedimentary strata toward the major fault.

One additional structural aspect of significance is the long life of major faults. A fault may be active for a period of time, then reactivated again much later. While the motion that is significant in sediment accumulation is the subsidence of the hanging wall, it is also possible for the footwall to move upward. Much of the exposure of once-buried strata in the Turkana Basin is due to footwall uplift during reactivation of normal faults. The Kokoi at Koobi Fora is actually a half-horst, in which the major bounding fault to the northwest is actively dropping the hanging wall, now beneath Lake Turkana. Footwall uplift has brought Gombe Group basalts to the surface after eroding some $500 \mathrm{~m}$ of Koobi Fora Formation strata. The capping sedimentary sequence is exposed in successive layers as one moves southeast off of Kokoi (Fig. B1, Part D).

reflected in the hominin-rich sands at Locality 261-1 in Allia Bay; the slowing of accumulation is likely reflected in the very poor fossil preservation through later parts of this interval. The Kerio River is seen at Kanapoi and is likely responsible for comparable fluvial sequences at Nakoret, Eshoa, and Longarakak. Much of the South Turkwell sequence ${ }^{69}$ records accumulation from the Turkwell River at this time. Similar deposits are seen in the Kaiyumung Member at Lothagam. Thus, the Moiti Floodplain was quite extensive as it occupied the infilled Lonyumun Lake basin.

The Moiti Floodplain was replaced over much of the depositional basin by a second lake phase, termed the 


\section{Box 2. The Contribution of Tephra}

Our understanding of the geological history of the Turkana Basin is heavily dependent on the versatility of tephra. As the products of explosive volcanism, the pumice, lapilli, and ash that comprise most tephra deposits make up a special class of sedimentary rocks. These materials may accumulate as primary airfall, direct from the source, or they may be secondarily deposited by fluvial action or aeolian reworking, or in mass movements as volcanic mudflows, termed lahars. In the Turkana Basin, tephra provide crucial material for geochemical correlation and isotopic dating. Because they are commonly intercalated within sedimentary sequences, much of our ability to date and correlate these strata, and their associated fossil and archeological assemblages, is based on tephra. The integration of tephra-based time horizons with detailed facies analysis provides a high-resolution approach to paleogeographic reconstruction.

Although not all tephra deposits can be directly dated, many contain primary mineral phases, especially potassium-rich feldspars, on which a

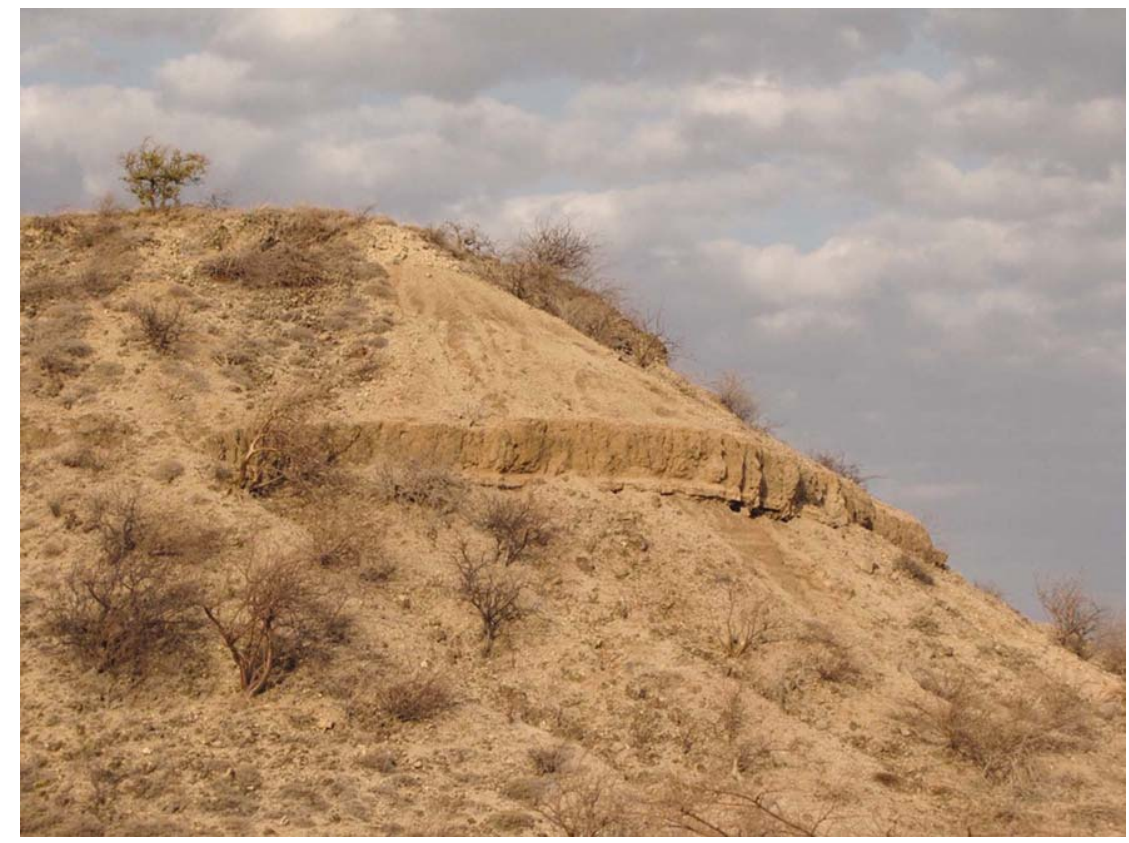

Figure B2. The KBS Tuff in Area 131 at Koobi Fora is a prominent lithostratigraphic marker, but can also be easily recognized on the basis of its geochemical composition and has been isotopically dated. Here the resistant bed of tuff is 1.2 meters thick. (Color figure can be viewed in the online issue, which is available at wileyonlinelibrary.com.) large proportion of the chronostratigraphic control of the fossil- and artifact-rich sediments of the Turkana Basin has been constructed. ${ }^{22,86}$ Even in situations in which the glass component of pumices has been weathered to clay minerals, datable crystals can sometimes be preserved. ${ }^{21,87}$ The application of tephra in correlation extends its utility far beyond simple dating, as complex frameworks can be constructed based on geochemical correlation of the primary glass or mineral phases. ${ }^{78,88}$ This has become a mainstay of navigating the complex spatial and temporal landscape of the Turkana Basin Plio-Pleistocene. ${ }^{89}$

In the Pliocene, three major tephra, the Moiti, Lokochot, and Tulu Bor, demonstrate the complexities of eruption and accumulation. All three were the products of extremely large eruptive sequences, producing voluminous tephra that was spread widely over East Africa and the Indian Ocean. ${ }^{90-92}$ Within the Turkana Basin, these tephra fell across the landscape as primary airfall. In a few localities, this airfall is preserved, but more commonly it was remobilized by local

\section{tut} gether. In both these cases, the different components or modes may be the products of different eruptions closely spaced in time, or sampling different parts of a magma chamber.

The rapid emplacement of individual tephra makes them ideal isochronous markers, of great significance to paleogeographic reconstruction. Tracing a tephra isochron across the Turkana Basin and placing it into the context of sedimentary facies allows detailed reconstruction of an individual paleolandscape. Early efforts with this approach were crucial in demonstrating that there were intervals of time when no lake was present in the basin, using fluvially deposited tephra that once were contiguous. ${ }^{94}$ Subsequent work has increased the detail of such reconstructions ${ }^{95}$ and made them useful in both envisioning ancient habitats and testing models of basin evolution. 
Box 3. Shifting Landscapes
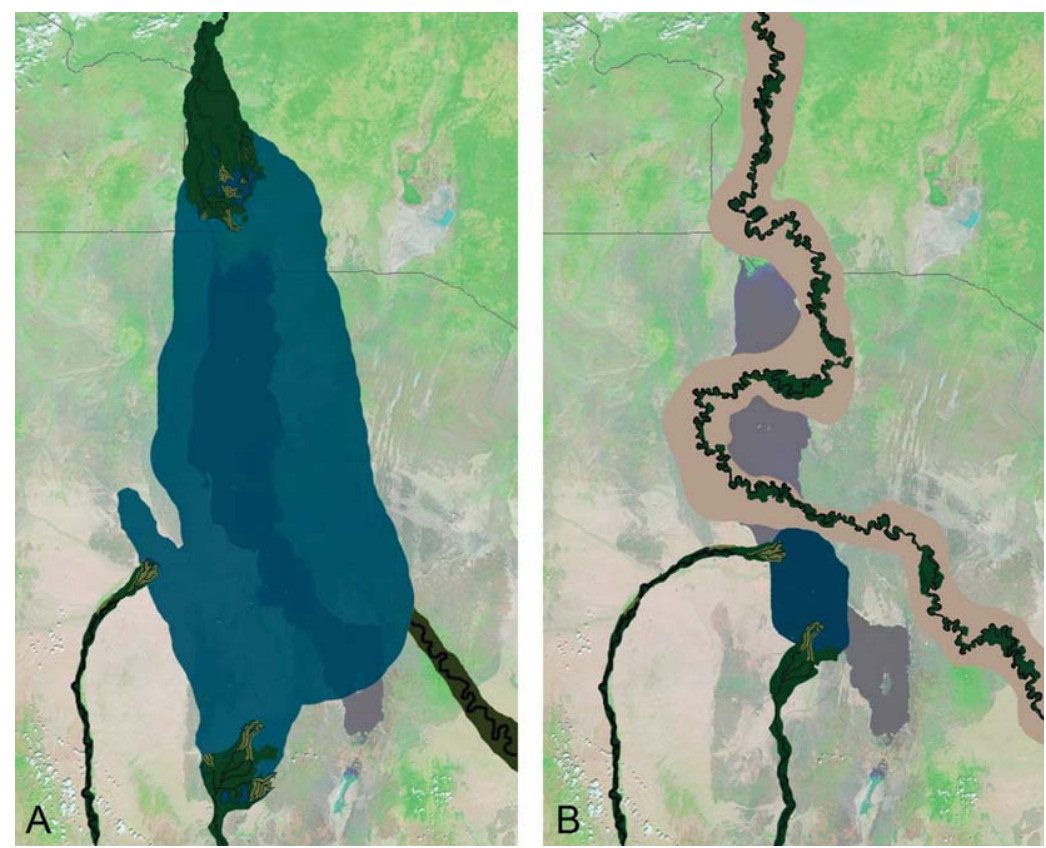

Figure B3. A. Paleogeographic reconstruction of the Lonyumun Lake (ca. 4.1 Ma), showing the extent of the lake as demonstrated by lacustrine facies, the Omo, Kerio and Turkwell deltas, and the presumed basin outlet in the southeast, leading to the Turkana River. B. Reconstruction of paleogeography at Moiti Tuff times $\left(3.97 \mathrm{Ma}^{86}\right.$ ) as demonstrated by the distribution of both channel and floodplain facies of the ancestral Omo River (using the Moiti Tuff isochron), as well as deltaic and paludal (marsh) facies preserved in the southwest. Both images show reconstructed paleogegraphic elements overlain on a modern satellite image (MODIS) for geographic reference.
The paleogeographic evolution of the Turkana Basin through the PlioPleistocene provides important clues to the spatial distribution and character of habitats and communities. Early reconstructions sought to reconcile stratigraphic information, facies interpretations, and tectonic patterns to understand the interplay between fluvial and lacustrine systems through time. ${ }^{94}$ Later, more detailed efforts began to unravel the complexities of shifting depositional systems in the rapidly aggrading fluvial and deltaic settings. ${ }^{67,75,96}$ The clear facies distinction between lacustrine strata and fluvial deposits, coupled with use of the basin's detailed tephrastratigraphic framework, allows the development of paleogeographic reconstructions, such as the extent of the Lonyumun Lake (Fig. B3, Part A). Mapping the depositional facies and extent of the subsequent Moiti Tuff demonstrates the evolution of the landscape as deltaic and fluvial succession infills of the lacustrine system, with only a small relict persisting in the southwest (Fig. B3, Part B).
Lokochot Lake. This stage in development of the basin begins a trend toward narrowing of the active depositional system and a general retreat from the southern localities. Thus, the Lokochot Lake is known from the lower Omo Valley to Nakoret, and Kataboi to Allia Bay. The lake was relatively shallow, and appears to have been largely infilled within about $60 \mathrm{ky}$. The deposits of this lake feature prominent diatomites in many areas. A major deltaic system is seen at Koobi Fora. The hominin Kenyanthropus platyops $^{70}$ was recovered from marginal alluvial deposits on the western side of Lokochot Lake.

The Lokochot Lake was succeeded by a long-lived floodplain system, here called the Tulu Bor Floodplain. Both Omo and Kerio river deposits through much of this interval preserve bioherms of the oyster Etheria; their abundance may be an indicator of a wetter climate though part of this time. There are also two short lacustrine phases in this interval, the Waru and Kokiselei lakes. They are more geographically restricted than other lakes, which may relate to localized subsidence of small structural blocks or to cut-and-fill behavior in response to climatic cycling. The earliest archeological sites in the basin are found on the Tulu Bor Floodplain, in West Turkana at Lokalalei and Nasura, ${ }^{47,71}$ and in the lower Omo Valley. ${ }^{72}$ They are found in association with the Omo River channel system and drainages coming off the basin margins.

Two significant changes began in the latter stages of the Tulu Bor Floodplain, the development of the Hamar Uplift to the northeast, and the beginnings of formation of the shield volcano Mt. Kulal in the southeast. The uplift in the northeast tilted that quadrant of the basin, leading to formation of an angular unconformity proximal to the uplift, which graded into an erosional disconformity, while the more distal western and southern portions of the depositional basin continued to accumulate sediments. A significant gap in the Koobi Fora succession, the Burgi Unconformity, is the result of this development. The growth of Mt. Kulal may have obstructed the basin outlet in the southeast, a remnant of the CARS physiography, deflecting drainage progressively northward, but not entirely blocking it. It is possible that this local interaction of the growing volcanic center with the fluvial corridor at the basin outlet was partly responsible for the subsequent stage in basin evolution, the formation of the Lorenyang Lake.

The Lorenyang Lake, the longestlived of the Neogene lakes, extended 
from the lower Omo Valley to Lothagam and Nakoret, and from Kokiselei to Shin. This long time interval witnessed a complex shifting of landscape elements, with lake, delta, and fluvial components replacing each other in quick succession. At the outset of this lake phase, the immigration of the Turkana stingray ${ }^{32}$ documents a fluvial outlet to the basin, the Turkana River, which presumably followed relict CARS topography via the Anza Graben to the Indian Ocean. Rapid subsidence in the northeast (the Koobi Fora region) allowed for a thick, detailed sedimentary record of this lake phase, beginning with pelagic (deep lake) deposits ${ }^{73}$ and continuing with a fluctuating lake margin in the East, ${ }^{74}$ while pelagic conditions persisted along the western side of the lake. Complex shifting of delta lobes is also recorded throughout the history of this lake. ${ }^{75}$ The high accumulation rates common to this lacustrine phase have allowed analysis of climatic cyclicity affecting the basin at this time, with water budgets driven primarily at a precessional (20 ky) time scale. ${ }^{73}$ The Turkana Basin's most celebrated tephrostratigraphic marker, the KBS Tuff, was erupted at this time. The paleogeography recorded by this isochronous marker details the transition from a fluvial and floodplain setting along the north and east to a deltaic lobe centered near Koobi Fora, while pelagic lacustrine conditions pertained from Kalochoro to Lothagam. ${ }^{18,67}$ These diverse depositional facies ${ }^{76}$ were also responsible for the accumulation of important fossils and archeological assemblages in a variety of settings. The early site of FwJj 20 north of Ileret was situated in an advancing delta lobe at about 1.95 $\mathrm{Ma},{ }^{77}$ while the hominin fossil KNMER 1470 was deposited by the delta only slightly later. KNM-ER 1813 is associated with the transition from active deltaic accumulation to fluctuating lake margin, while KNM-ER 3733 was deposited at a later stage of the Koobi Fora lake margin succession. The Nariokotome skeleton KNM-WT 15000 was buried in a floodplain marsh near the end of the Lorenyang Lake phase. ${ }^{78}$
The complex accumulation pattern of the Lorenyang Lake interval was succeeded by an equally complex culmination of Omo Group depositional history, but one in which short intervals of accumulation were followed by increasingly significant gaps in the record, and through which the geographic locus of sedimentation was increasingly focused in the northerly parts of the depositional basin. A short-lived return of a largescale fluvial landscape occurred in the Chari Floodplain. This was followed by an enigmatic lacustrine phase, termed here the Nachukui Lake. This interval is well-represented by major beach complexes at Nachukui, and by broadly correlative lacustrine strata at Ileret and in the lower Omo Valley. At present, however, this episode is poorly constrained. A final floodplain episode, termed the Silbo Floodplain is likely the last record of the large fluvial systems of the Omo Group. It is particularly noteworthy in that fluvial deposits incorporating boulder-size pumices of the Silbo Tuff are found on the northeastern basin margin near Shin. These may suggest a last linkage to the CARS heritage of the Anza Graben and a final stage in the eastern outlet forming the Turkana River.

The cessation of Omo Group accumulation at approximately $700 \mathrm{Ka}^{79}$ leaves a gap of half a million years in basin history before the known record of the modern lake. This gap suggests that while the main contributors to the system, the Omo, Turkwell, and Kerio rivers, must have persisted, there was little or no accommodation space within the basin for them to leave a sedimentary record. Undoubtedly some of this time is represented by the sequence beneath the northern part of the modern lake, but it is also possible that the switch-over in the basin outlet, from eastward-draining to the northwest connection with the Nile system was established in this interval.

\section{Lake Turkana}

The most recent phase of sedimentary accumulation in the basin is related to the formation of Lake Turkana. The earliest record of this lakedominated system derives from the basal Turkana Group strata, the Kibish Formation of the lower Omo Valley. ${ }^{80}$ The earliest transgression of modern Lake Turkana took place shortly before $200 \mathrm{Ka}^{81}$ The structural reorganization associated with this latest phase of basin evolution focused subsidence on a narrower central half-graben system. Associated with this system was deformation of the marginal Omo Group strata on the outlying western and eastern basin margins (essentially the Koobi Fora and West Turkana regions), as well as block uplifts such as the Kokoi half-horst and the Shungura block.

Depositional patterns in the Turkana Group reflect two agents controlling sediment character: the major deltas (Omo and TurkwellKerio) and the lake itself. The sedimentary style of the early Kibish Formation demonstrates the interplay between base-level fluctuations of Lake Turkana and the progradation-incision cycling of the Omo River in the north. Lowstand infilling near the onset of this interval formed the context for preservation of the Omo I and II crania from Kibish. ${ }^{82,83}$ McDougall, Brown, and Fleagle ${ }^{81}$ have elegantly demonstrated the precessional (20 ky) cyclicity in this phase of sedimentation. The last Interglacial (OIS 5e) through last Glacial (OIS 2) do not appear to be reflected in the sedimentary record of the basin. This may imply diversion of the Omo River out of the basin in the north or simply lowstand conditions during which accumulation was largely limited to parts of the basin currently under the modern lake.

A major transgression of Lake Turkana, recorded in the Galana Boi Formation ${ }^{84}$ and Member IV of the Kibish Formation began around $12,000 \mathrm{y} \mathrm{BP},{ }^{80}$ contemporaneous with other highstands in the region, such as Suguta Valley. ${ }^{85}$ Even in the lower Omo Valley, this phase is strongly dominated by lacustrine sedimentation, with diatomaceous silts and coquinas, suggesting that mega-Lake Turkana, as an open-basin, freshwater system, was distinctly different from the earlier stages of Turkana Group history reflected in 
Kibish I-III. The subsequent history of Lake Turkana is known primarily from study of sediments beneath the modern lake, ${ }^{29}$ as the system shifted to the closed basin configuration of the present day, and lake levels have oscillated in response to short-term climatic variations.

\section{SUMMARY}

The Turkana Basin has a long and varied geologic history, preserving important windows into the geological development of East Africa, evolution in important fossil groups since the Cretaceous, and the biological and cultural development of our own ancestors. The interaction of tectonic controls, climatic fluctuations, and volcanic influences with the succession of landscapes and habitats formed the basis for past dynamics within the basin and are reflected in its complex sedimentary strata.

\section{ACKNOWLEDGMENTS}

My thanks to all of the Turkana geologists, who have built the framework and made the observations on which this contribution is based. Special thanks to Richard and Meave Leakey, for their unflagging support over many years and many projects. Portions of this work were supported by grants from the National Science Foundation and the Leakey Foundation.

\section{REFERENCES}

1 von Höhnel L. 1894. Discovery of Lakes Rudolf and Stefanie: a narrative of Count Samuel Teleki's exploring and hunting expedition in eastern Equatorial Africa in 1887-1888. London: Longman's and Green.

2 Coppens Y, Howell FC, Isaac GL, Leakey REF, editors. 1976. Earliest man and environments in the Lake Rudolf basin. Chicago: University of Chicago Press.

3 Fuchs VE. 1939. The geological history of the Lake Rudolf Basin, Kenya Colony. Philos Trans R Soc London 229B:219-274.

4 Boschetto HB, Brown FH, McDougall I. 1992. Stratigraphy of the Lothidok Range, northern Kenya, and K/Ar ages of its Miocene primates. J Hum Evol 22:47-71.

5 Joubert P. 1966. Geology of the Loperot area. Report Geol Survey Kenya 74:1-52.

6 Walsh J, Dodson RG. 1969. Geology of northern Turkana. Report Geol Survey Kenya 82:1-42.

7 Dodson RG. 1971. Geology of the area south of Lodwar. Report Geol Survey Kenya 60:1-53.
8 Davidson A. 1983. The Omo River Project. Ethiopian Inst Geol Surveys Bull 2:1-89.

9 Charsley TJ. 1987. Geology of the North Horr area. Report Mines Geol Dept Kenya 110:1-40.

10 Ochieng' JO, Wilkinson AF, Kagasi J Kimono S. 1988. Geology of the Loiyangalani area. Report Mines Geol Dept Kenya 107:1-53.

11 Key RM, Watkins RT. 1988. Geology of the Sabarei area. Report Mines Geol Dept Kenya 111:1-57.

12 Wilkinson AF. 1988. Geology of the Allia Bay area. Report Mines Geol Dept Kenya 109:1-54.

13 Hackman BD, Charsley TJ, Rey RH, Wilkinson AF. 1990. The development of the East African Rift System in north central Kenya. Tectonophysics 184:189-211.

14 de Heinzelin J, editor. 1983. The Omo Group. Tervuren: Musée Royal de l'Afrique Centrale. Annales, Série in 8o, Sciences Géologiques 85 .

15 Bowen BE, Vondra CF. 1973. Stratigraphical relationships of the Plio-Pleistocene deposits, East Rudolf, Kenya. Nature 242:391-393.

16 Brown FH, Feibel CS. 1986. Revision of lithostratigraphic nomenclature in the Koobi Fora region, Kenya. J Geol Soc London 143:297-310.

17 Harris JM, Brown FH, Leakey MG. 1988. Geology and paleontology of Plio-Pleistocene localities west of Lake Turkana, Kenya. Contrib Sci 399:1-128.

18 Feibel CS. 2003. Stratigraphy and depositional history of the Lothagam sequence. In: Leakey MG, Harris JM, editors. Lothagam: The dawn of humanity in Eastern Africa. New York: Columbia University Press. p 17-29.

19 Feibel CS. 2003. Stratigraphy and depositional setting of the Pliocene Kanapoi Formation, lower Kerio Valley, Kenya. Contrib Sci 498:920

20 Zanettin B, Justin-Visentin E, Bellieni G, Piccirillo EM, Rita F. 1983. Le volcanisme du bassin du Nord-Turkana (Kenya): age, succession et évolution structurale. Bull Centres Recherches Exploration-Production Elf-Aquitaine 7:249-255.

21 McDougall I, Feibel CS. 1999. Numerical age control for the Miocene-Pliocene succession at Lothagam, a hominoid-bearing sequence in the northern Kenya Rift. J Geol Soc London 156:731-745.

22 McDougall I, Brown FH. 2006. Precise ${ }^{40} \mathrm{Ar} /{ }^{39} \mathrm{Ar}$ geochronology for the upper Koobi Fora Formation, Turkana Basin, northern Kenya. J Geol Soc London 165:205-220.

23 Brown FH, McDougall I. 2011. Geochronology of the Turkana Depression. Evol Anthropol 24 Gradstein F, Ogg J, Smith A, editors. 2004. A geologic time scale. Cambridge: Cambridge University Press.

25 Morley CK, editor. 1999. Geoscience of rift systems: evolution of East Africa. Tulsa: AAPG. 26 Tiercelin JJ, Potdevin JL, Morley CK, Talbot MR, Bellon H, Rio A, Le Gall B, Vétel W. 2004. Hydrocarbon potential of the Meso-Cenozoic Turkana Depression, northern Kenya. I. Reservoirs: depositional environments, diagenetic characteristics, and source rock-reservoir relationships. Marine Petroleum Geol 21:41-62.

27 Dunkley PN, Smith M, Allen DJ, Darling WG. 1993. The geothermal activity and geology of the northern sector of the Kenya Rift Valley. Br Geol Survey Res Report SC/93/1:1-185.

28 Johnson TC, Halfman JD, Rosendahl BR, Lister JS. 1987. Climatic and tectonic effects on sedimentation in a rift-valley lake: evidence from high-resolution seismic profiles, Lake Turkana, Kenya. Geol Soc Am Bull 98:439-447.
29 Johnson TC, Halfman JD, Showers WJ. 1991. Paleoclimate of the past 4000 years at Lake Turkana, Kenya, based on the isotopic composition of authigenic calcite. Palaeogeogr Palaeoclimatol Palaeoecol 85:189-198.

30 Bosworth W. 1992. Mesozoic and early Tertiary rift tectonics in East Africa. Tectonophysics 209:115-137.

31 Thuo P. 2009. Stratigraphic, petrographic and diagenetic evaluation of Cretaceous/Paleogene potential reservoir sandstones of western Turkana, Kenya. Bretagne: University of Bretagne. 32 Feibel CS. 1994. Freshwater stingrays from the Plio-Pleistocene of the Turkana Basin, Kenya and Ethiopia. Lethaia 26:359-366.

33 Dunkelman TJ, Karson JA, Rosendahl BR. 1988. Structural style of the Turkana Rift, Kenya. Geology 16:258-261.

34 Van Bocxlaer B, Van Damme D, Feibel CS. 2008. Gradual versus punctuated equilibrium evolution in the Turkana Basin molluscs: evolutionary events or biological invasions? Evolution 62:511-520.

35 Schlüter T. 1997. Geology of East Africa. Berlin: Gebrüder Borntraeger.

36 de Lumley H, Beyene Y, editors. 2004. Les sites préhistoriques de la région de Fejej, SudOmo, Ethiopie, dans leur contexte stratigraphique et paléontologique. Paris: Editions Recherches sur les Civilisations.

37 Delagnes A, Boisserie J-R, Beyene Y, Chuniaud K, Guillemot C, Schuster M. 2011. Archaeological investigations in the Lower Omo Valley (Shungura Formation, Ethiopia): New data and perspectives. J Hum Evol 61:215-222. 38 Merrick HV. 1976. Recent archaeological research in the Plio-Pleistocene deposits of the lower Omo Valley, southwestern Ethiopia. In: Isaac GL, McCown ER, editors. Human origins: Louis Leakey and the East African evidence. Menlo Park: W. A. Benjamin. p 460-482.

39 Bellieni G, Justin Visentin E, Picirillo EM, Zanettin B. 1987. Volcanic cycles and magmatic evolution in northern Turkana (Kenya). Tectonophysics 143:161-168).

40 Watkins RT. 1983. The geology of the Suregei-Asille district and the upper Bakate Valley, northern Kenya. London: Birkbeck College, University of London.

41 Boschetto HB. 1988. Geology of the Lothidok Range, northern Kenya. Salt Lake City: University of Utah.

42 Haileab B, Brown FH, McDougall I, Gathogo PN. 2004. Gombe Group basalts and initiation of Pliocene deposition in the Turkana depression, northern Kenya and southern Ethiopia. Geol Mag 141:41-53.

43 Watkins RT. 1986. Volcano-tectonic control on sedimentation in the Koobi Fora sedimentary basin, Lake Turkana. In: Frostick LE, Renaut RW, Reid I, Tiercelin JJ, editors. Sedimentation in the African rifts. Oxford: Blackwell. p 85-95.

44 Watkins RT. 1987. Geology of Kubi Algi and Derati Mountains, pantellerite bodies of Miocene age from the northern part of the Kenyan Rift Valley. J African Earth Sci 6:603-616.

45 Watkins RT. 1989. The Buluk Member, a fossil hominoid-bearing sedimentary sequence of Miocene age from northern Kenya. J African Earth Sci 8:107-112.

46 Karson JA, Curtis PC. 1994. Quaternary volcanic centres of the Turkana Rift, Kenya. J African Earth Sci 18:15-35.

47 Roche H, Brugal J-P, Delagnes A, Feibel C, Harmand S, Kibunjia M, Prat S, Texier P-J. 2004. Plio-Pleistocene archaeological sites in 
the Nachakui Formation, West Turkana, Kenya: Synthetic results 1997-2001. Comptes Rendus Palevol 2:663-673.

48 Handford CR. 1987. Turkana Grits: a Cretaceous braided alluvial system in northern Kenya. AAPG Bull 71:564.

49 Sertich JJW, Sampson SD, Loewen MA Getty MA, Manthi FK. 2006. Rift valley dinosaurs: a new Late Cretaceous vertebrate fauna from Kenya. J Vertebrate Paleontol 26(suppl 3): $124 \mathrm{~A}$.

50 O'Connor PM, Sertich JJW, Manthi FK. 2011. A pterodactyloid pterosaur from the Upper Cretaceous Lapurr sandstone, West Turkana, Kenya. Anais da Academia Brasileira de Cièncias 83:309-315.

51 McDougall I, Brown FH. 2009. Timing of volcanism and evolution of the northern Kenya Rift. Geol Mag 146:34-47.

52 Leakey MG, Ungar PS, Walker A. 1995. A new genus of large primate from the Late Oligocene of Losodok, Turkana District, Kenya. J Hum Evol 28:519-531.

53 Rasmussen DT, Gutierrez M. 2009. A mammalian fauna from the Late Oligocene of northwestern Kenya. Palaeontogr Abteilung A 288: $1-52$.

54 Ducrocq S, Boisserie JR, Tiercelin JJ Delmer C, Garcia G, Kyalo MF, Leakey MG, Marivaux L, Otero O, Peigné S. 2010. New Oligocene vertebrate localities from northern Kenya (Turkana Basin). J Vertebrate Paleontol 30:293-299.

55 Morley CK, Wescott WA, Stone DM, Harper RM, Wigger ST, Karanja FM, Day RA. 1999. Geology and geophysics of the western Turkana basins. In: Morley CK, editor. Geoscience of Rift Systems: Evolution of East Africa. Tulsa: AAPG. p 19-54.

56 Talbot MR, Morley CK, Tiercelin JJ, Le Hérissé A, Potdevin JL, Le Gall B. 2004. Hydrocarbon potential of the Meso-Cenozoic Turkana Depression, northern Kenya. II. Source rocks: quality, maturation, depositional environments and structural control. Marine Petroleum Geol 21:63-78.

57 Vincens A, Tiercelin JJ, Buchet G. 2006. New Oligocene-early Miocene microflora from the southwestern Turkana Basin: palaeoenvironmental implications in the northern Kenya Rift. Palaeogeogr Palaeoclimatol Palaeoecol 239:470-486.

58 McDougall I, Watkins RT. 2006. Geochronology of the Nabwal Hills: a record of earliest magmatism in the northern Kenyan Rift Valley. Geol Mag 143:25-39.

59 Mead JG. 1975. A fossil beaked whale (Cetacea: Ziphiidae) from the Miocene of Kenya. J Paleontol 49:745-751.

60 Leakey RE, Leakey MG. 1986. A new Miocene hominoid from Kenya. Nature 324: 143-146.

61 Leakey RE, Leakey MG. 1986. A second new hominoid from Kenya. Nature 324:146-148.

62 Anyonge W. 1991. Fauna from a new lower Miocene locality west of Lake Turkana, Kenya. J Vertebrate Paleontol 11:378-390.

63 Leakey MG, Harris JM, editors. 2003. Lothagam: The dawn of humanity in Eastern Africa. New York: Columbia University Press.

64 Powers DW. 1980. Geology of Mio-Pliocene sediments of the lower Kerio River Valley. Princeton: Princeton University.

65 Wynn J. 2003. Miocene Paleosols of Lothagam Hill. In: Leakey MG, Harris JM, editors.
Lothagam: the dawn of humanity in Eastern Africa. New York: Columbia University Press. p 31-42.

66 Wynn JG. 2000. Paleosols, stable carbon isotopes, and paleoenvironmental interpretation of Kanapoi, northern Kenya. J Hum Evol 39: 411-432.

67 Feibel CS. 1988. Paleoenvironments from the Koobi Fora Formation, Turkana Basin, northern Kenya. Salt Lake City: University of Utah.

68 Watkins RT. 1986. Volcano-tectonic control on sedimentation in the Koobi Fora sedimentary basin, Lake Turkana. In: Frostick LE, Renaut RW, Reid I, Tiercelin JJ, editors. Sedimentation in the African rifts. Oxford: Blackwell. p 85-95.

69 Ward CV Leakey MG, Brown B, Brown F, Harris J, Walker A. 1999. South Turkwel: a new Pliocene hominid site in Kenya. J Hum Evol 36:69-95.

70 Leakey MG, Spoor F, Brown FH, Gathogo PN, Kiarie C, Leakey LN, McDougall I. 2001. New hominin genus from eastern Africa shows diverse middle Pliocene lineages. Nature 410: 433-440.

71 Roche H, Delagnes A, Brugal JP, Feibel CS, Kibunjia M, Mourre V, Texier PJ. 1999. Early hominid stone tool production and technical skill 2.34 Myr ago in West Turkana, Kenya. Nature 399:57-60.

72 Howell FC, Haesaerts P, de Heinzelin J. 1987. Depositional environments, archeological occurrences and hominids from Members E and $\mathrm{F}$ of the Shungura Formation (Omo basin, Ethiopia). J Hum Evol 16:665-700.

73 Joordens JCJ, Vonhof HB, Feibel CS, Lourens LJ, Dupont-Nivet G, van der Lubbe JHJL, Sier MJ, Davies GR, Kroon D. 2011. An astronomically-tuned climate framework for hominins in the Turkana Basin. Earth Planetary Sci Lett 307:1-8.

74 Lepre CJ, Quinn RL, Joordens JJ, Swisher CC, Feibel CS. 2007. Pleistocene facies environments from the KBS Member, Koobi Fora Formation: implications or climate controls on the development of lake-margin hominin habitats in the northeast Turkana Basin (northwest Kenva). J Hum Evol 53:504-514.

75 Feibel CS, Lepre CJ, Quinn RL. 2009. Stratigraphy, correlation, and age estimates for fossils from Area 123, Koobi Fora. J Hum Evol $57: 112-122$

76 Feibel CS. n.d. Facies and Pliocene paleoecology. In: Sponheimer M, Lee-Thorp J, Reed $\mathrm{K}$, Ungar P, editors. Early hominin paleoecology. Boulder: University of Colorado Press.

77 Braun DR, Harris JWK, Levin NE, McCoy JT, Herries AIR, Bamford MK, Bishop LC Richmond BG, Kibunjia M. 2010. Early hominin diet included diverse terrestrial and aquatic animals 1.95 Ma in East Turkana, Kenya. Proc Natl Acad Sci USA 107:1000210007.

78 Feibel CS, Brown FH. 1993. Microstratigraphy and paleoenvironments. In: Walker AC Leakey RE, editors. The Nariokotome Homo erectus skeleton. Cambridge: Harvard University Press. p 21-39.

79 Feibel CS, Brown FH, McDougall I. 1989. Stratigraphic context of fossil hominids from the Omo Group deposits, northern Turkana Basin, Kenya and Ethiopia. Am J Phys Anthropol 78:595-622.

80 Brown FH, Fuller CR. 2008. Stratigraphy and tephra of the Kibish Formation, southwestern Ethiopia. J Hum Evol 55:366-403.
81 McDougall I, Brown FH, Fleagle JG. 2005. Stratigraphic placement and age of modern humans from Kibish, Ethiopia. Nature 433: 733-736

82 Feibel CS. 2008. Microstratigraphy of the Kibish hominin sites KHS and PHS, lower Omo Valley, Ethiopia. J Hum Evol 55:404-408.

83 Fleagle JG, Assefa Z, Brown FH, Shea JJ. 2008. Paleoanthropology of the Kibish Formation, southern Ethiopia: introduction. J Hum Evol 55:360-365.

84 Owen RB, Renaut RW. 1986. Sedimentology, stratigraphy and paleoenvironments of the Holocene Galana Boi Formation, NE Lake Turkana, Kenya. In: Frostick LE, Renaut RW, Reid I, Tiercelin JJ, editors. Sedimentation in the African rifts. Oxford: Blackwell. p 311322.

85 Garcin Y, Junginger A, Melnick D, Olago DO, Strecker MR, Trauth MH. 2009. Late-Pleistocene-Holocene rise and collapse of Lake Suguta, northern Kenya Rift. Quaternary Sci Rev 28:911-925.

86 McDougall I, Brown FH. 2008. Geochronology of the pre-KBS Tuff sequence, Turkana Basin. J Geol Soc London 165:549-562.

87 Leakey MG, Feibel CS, McDougall I, Walker A. 1995. New four-million-year-old hominid species from Kanapoi and Allia Bay, Kenya. Nature 376:565-571.

88 Feibel CS. 1999. Tephrostratigraphy and geological context in paleoanthropology. Evol Anthropol 8:87-100.

89 Brown FH, Haileab B, McDougall I. 2006. Sequence of tuffs between the KBS Tuff and the Chari Tuff in the Turkana Basin, Kenya and Ethiopia. J Geol Soc London 163: 185-204.

90 Brown FH, Sarna-Wojcicki AM, Meyer CE, Haileab B. 1992. Correlation of Pliocene and Pleistocene tephra layers between the Turkana Basin of East Africa and the Gulf of Aden. Quaternary Int 13/14:55-67.

91 Pickford M, Senut B, Poupeau G, Brown F, Haileab B 1991. Correlation of tephra layers from the Western Rift Valley (Uganda) to the Turkana Basin (Ethiopia/Kenya) and the Gulf of Aden. Comptes Rendus des Sceances de l'Academie des Sciences, Paris 313:223-229.

92 Sarna-Wojcicki AM, Meyer CE, Roth PE, Brown FH. 1985. Ages of tuff beds at East African early hominid sites and sediments in the Gulf of Aden. Nature 313:306-308.

93 Cerling TE, Brown FH. 1982. Tuffaceous marker horizons in the Koobi Fora region and the lower Omo valley. Nature 299:216-221.

94 Brown FH, Feibel CS. 1988. "Robust" hominids and Plio-Pleistocene paleogeography of the Turkana Basin, Kenya and Ethiopia. In: Grine FE, editor. Evolutionary history of the "robust" australopithecines. New York: Aldine de Gruyter. p 325-341.

95 Feibel CS, Harris JM, Brown FH. 1991. Palaeoenvironmental context for the late Neogene of the Turkana Basin. In: Harris JM, editor. Koobi Fora Research Project, vol 3. Stratigraphy, artiodactyls and palaeoenvironments. Oxford: Clarendon Press. p 321-370.

96 Brown FH, Feibel CS. 1991. Stratigraphy, depositional environments and paleogeography of the Koobi Fora Formation. In: Harris JM, editor. Koobi Fora Research Project, vol 3. Stratigraphy, artiodactyls and paleoenvironments. Oxford: Clarendon Press. p 1-30. 